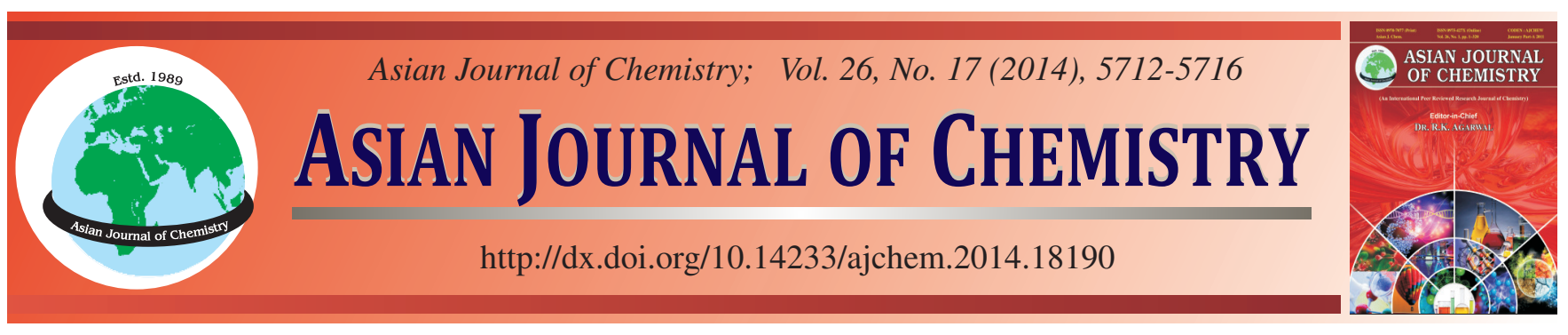

\title{
Effects of Surface-Modified Graphite on Tribological Properties and Thermal Conductivity of Fabric Self-Lubricating Liner $\dagger$
}

Zhanqi Hu, Zhanshan Wang, Jigang Chen, Bingli Fan, Xiaowen Qı , Jian Ma, Dapeng Gu, Yulin Yang and Laizhou Song

Aviation Key Laboratory of Science and Technology on Generic Technology of Self-Lubricating Spherical Plain Bearing, Yanshan University, Qinhuangdao 066004, P.R. China

*Corresponding author: E-mail: qxw_tougao@163.com

\begin{abstract}
The surface-modified graphite powder was used as high thermal conductivity filler to fabricate the woven structure fabric self-lubricating liner. Thermal conductivity and tribological properties of the fabric self-lubricating liners filled with graphite were investigated using KY-DRX-RW tester and MMU-5G tribological tester, respectively. Results showed that the thermal conductivity of the liner filled with 10 wt. $\%$ graphite was improved by about $15 \%$ under normal temperature comparing with liner without graphite. By affecting the viscosity of the tribofilm, the graphite improved the wear resistance of the fabric liner filled with graphite and showed opposite effect on the antifriction property. In particular, fabric self-lubricating liner filled with $10 \mathrm{wt} \%$ graphite showed relatively high thermal conductivity, significant low wear loss, slightly increased but steady friction coefficient and integrated weave structure.
\end{abstract}

Keywords: Surface-modified graphite, Thermal conductivity, Tribological property, Fabric self-lubricating liner.

\section{INTRODUCTION}

The fabric self-lubricating liner has been widely applied in spherical plain bearings as a service life determination component. The main friction form of the spherical plain bearing is sliding friction and there is not lubricant medium such as lubricating oil or grease. Thus, diffusion of the friction heat generated in friction mainly relies on the fabric self-lubricating liner-a kind of woven polymer composite comprised of resin, PTFE and aramid fibers and other fillers. However, the thermal conductivity of polymers is normally ${ }^{1}$ around $0.2 \mathrm{~W} \mathrm{~m}^{-1} \mathrm{~K}^{-1}$ which is quite lower than materials such as stainless steel, whose thermal conductivity ${ }^{2}$ is nearly $20 \mathrm{~W} \mathrm{~m}^{-1} \mathrm{~K}^{-1}$. The low thermal conductivity of the fabric self-lubricating liner blocks the heat transfer and results in heat concentration in the liner, which may leads to aging of the polymer composite and damage of the woven structure, even functional failure of the spherical plain bearings. Therefore, improving the thermal conductivity of the fabric self-lubricating liner becomes an incredibly important issue.

Many attempts have been made to improve the thermal conductivity of polymers and polymer matrix composites. One of the most efficient and desirable way is to fill high thermal conductivity additive, such as graphite, carbon fibers, ceramic or metal particles, carbon nano-tubes, to the polymers or composites to develop new material ${ }^{3-8}$. A high thermal conductivity of $10 \mathrm{~W} \mathrm{~m}^{-1} \mathrm{~K}^{-1}$ could be achieved when satisfactory content and properly dispersed fillers are $\operatorname{added}^{9}$. Graphite has favorable properties of self-lubricating, thermostability and anti-erosion and is regularly used in fabrication of selflubricating materials, as well as in improving tribological properties and thermal conductivity of composites. Both mechanical and tribological properties of the glass-epoxy composites were improved while filled with $7.5 \mathrm{wt}$. \% graphite particulate filler ${ }^{10}$. Reports about enhancement of the wear resistance of graphite filled epoxy ${ }^{11}$, tribological behaviour of PEEK based composites ${ }^{12}$, copper-coated graphite filled PTFE composites $^{13}$ and carbon-nanofibre-reinforced poly(ether ketone $)^{14}$ reflected the usefulness of the graphite on tribological properties of various composites. By mixing solid lubricant graphite and h-BN into $\mathrm{Cu}$-based $\mathrm{P} / \mathrm{M}$ friction composites, the wear resistance of the composites was increased and the wear rate significantly dropped when the graphite content increased $^{15}$. Different volume percentage of graphite powder was added in bakelite $\left(1.4 \mathrm{~W} \mathrm{~m}^{-1} \mathrm{~K}^{-1}\right)$ to improve its thermal conductivity and an enhancement of thermal conductivity from 4.84 to $12.28 \mathrm{~W} \mathrm{~m}^{-1} \mathrm{~K}^{-1}$ was achieved with increasing volume percentage of graphite powder from 30 to $55 \%{ }^{16}$. Similar 
enhancements of the thermal conductivity of different graphite filled composites have also been achieved ${ }^{17-20}$. However, to our best aware, reports about graphite-filled fabric self-lubricating liner is rare.

In present paper, different contents of graphite powder was filled in the woven structure fabric self-lubricating liner and thermal conductivity, friction coefficient, wear loss and worn surface morphologies of the liners were investigated. Combining the experimental results, mechanisms of graphite powder affects thermal conductivity and tribological properties of the fabric self-lubricating liner were developed. All the works are intend to improve the practicality and service life of the self-lubricating liner and spherical plain bearings under actual applications.

\section{EXPERIMENTAL}

Fabrication of the graphite filled fabric self-lubricating liner: The satin-weave fabric was woven by Y200S Electronic Sample Loom (NanTong SanSi Electromechanical Science \& Technology Co., Ltd., China). PTFE fiber (Shanghai Lingqiao Environment Protecting Equipment Works Co., Ltd.) was used in weft direction and aramid fiber (Kevlar 49, DuPont, USA) was used in warp direction. The phenolic-acetal resin was supplied by Shanghai Xinguang Chemical Co., Ltd. of China. The crystal shape graphite with an average particle size of 13 $\mu \mathrm{m}$ was supplied by Shanghai CW-Nano Co., Ltd. To avoid agglomeration of the graphite powder during liner preparation, a kind of silane coupling agent, $\mathrm{KH} 550\left(\mathrm{H}_{2} \mathrm{~N}\left(\mathrm{CH}_{2}\right)_{3} \mathrm{Si}\left(\mathrm{OC}_{2} \mathrm{H}_{5}\right)_{3}\right)$, was used to conduct surface modification. Figs. 1 and 2 show images of the graphite powder and the woven fabric, respectively.

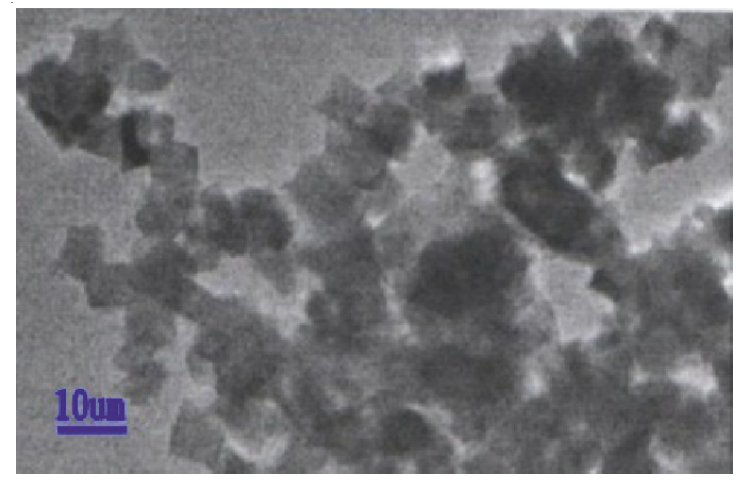

Fig. 1. Image of the graphite powder

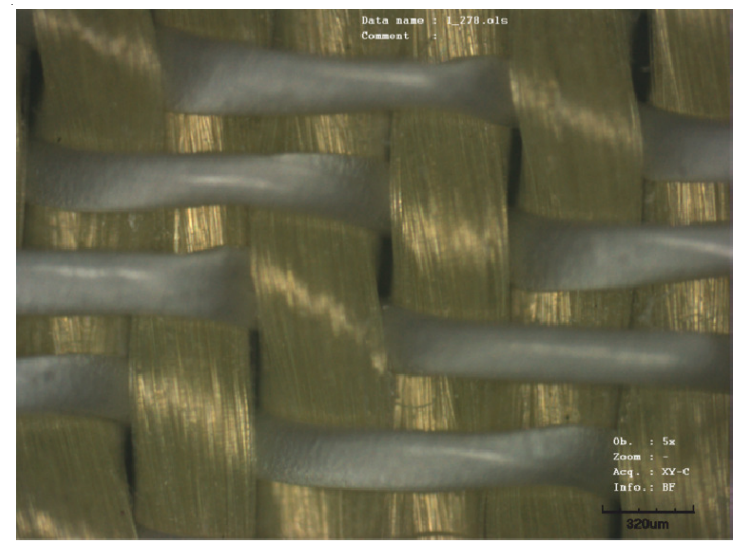

Fig. 2. Confocal laser scanning microscopy image of the woven fabric
The woven fabric was first soaked in acetone for $24 \mathrm{~h}$. After boiled for $20 \mathrm{~min}$ in distilled water, the fabric was dried in drying oven (GZX-90701MBE, Shanghai Boxun Industry and Commerce Co., Ltd., China) for $1 \mathrm{~h}$ at $80^{\circ} \mathrm{C}$. Certain mass of KH550 was dissolved in ethanol solution and then certain percentage of graphite powder was added in the solution, which was subsequently stirred using a heat collection magnetic stirring apparatus (DF101B, Automize The Instrument Plant On The Earth of Jintan City, China) for $1 \mathrm{~h}$ and conducted ultrasonic treatment (FS-600N, Shanghai Sonxi Ultrasonic Instrument, China) for $15 \mathrm{~min}$ under $60 \mathrm{~W}$ to dispersed the graphite powder uniformly. The solution was immediately added in certain percentage of resin and re-stirred for $0.5 \mathrm{~h}$ and conducted ultrasonic treatment for $1 \mathrm{~h}$ under $80 \mathrm{~W}$. After these pre-works, the dried fabric was soaked in the resin for 1 $\mathrm{h}$ at $40^{\circ} \mathrm{C}$. Then a glass rod was used to roll out the spare resin and bubble. After dried in the oven for $2 \mathrm{~h}$ at $110^{\circ} \mathrm{C}$, the graphite filled fabric self-lubricating liner was fabricated. To complete the lower specimen, half-solidified fabric self-lubricating liner was spliced using phenolic resin on circular C45 steel which was polished successively using CW-500 and CW-1000 silicon carbide water proof electro coated abrasive paper and cleaned with absolute ethyl alcohol. After drying for $2 \mathrm{~h}$ under condition of $180^{\circ} \mathrm{C}$ and $0.2 \mathrm{MPa}$, the lower specimen was completely finished.

Tribological tests: The MMU-5G digital material tribological tester (Jinan SiDa Instruments Co., Ltd., China) was used to conduct tribological experiments. The upper specimen (C45 steel) was polished successively using CW-500 and CW-1000 silicon carbide water proof electro coated abrasive paper till its surface roughness was $0.16-0.22 \mu \mathrm{m}$ and cleaned by ethyl alcohol. Fig. 3 shows the structural diagram of the friction tester. The experiments were conducted under load of $10 \mathrm{MPa}$, speed of $375 \mathrm{rpm}$ and test time of $7200 \mathrm{~s}$ under room temperature.

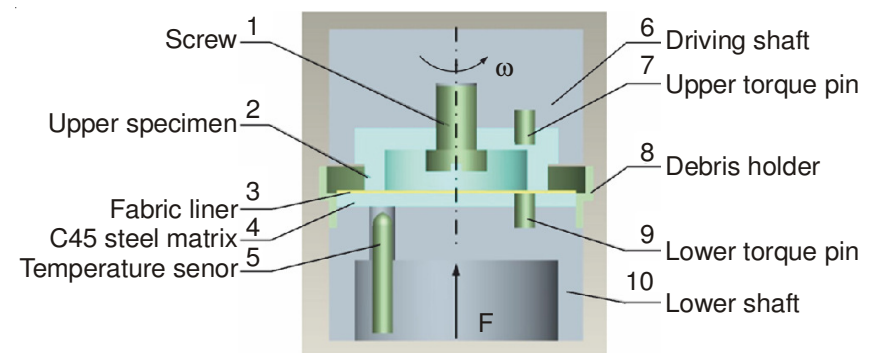

Fig. 3. Structual diagram of the friction tester

The friction coefficient and temperature can be recorded by the tester online. The wear depth was measured using fabric thickness equipment (YG141D) and the wear loss can be obtained by eqn. 1 . To lower the measurement error, the average thickness values of 10 points were calculated each time.

$$
\mathrm{w}=\frac{1}{\mathrm{~N}} \sum_{\mathrm{i}=1}^{\mathrm{N}}\left(\mathrm{H}_{\mathrm{oi}}-\mathrm{H}_{\mathrm{i}}\right)
$$

where $\mathrm{w}$ is the wear loss of the fabric self-lubricating liner; $\mathrm{N}$ is the measurement point number $(\mathrm{N}=10) ; \mathrm{H}_{\mathrm{oi}}$ is the original thickness of the sample point and $\mathrm{H}_{\mathrm{i}}$ is the thickness of the corresponding point of the liner after friction. 
Thermal conductivity tests: The thermal conductivity tester (KY-DRX-RW, Shanghai Shibo Instrument Co., Ltd., China) was used to record thermal conductivities of the fabric self-lubricating liners with different content graphite filler. Image of the KY-DRX-RW tester was shown in Fig. 4.

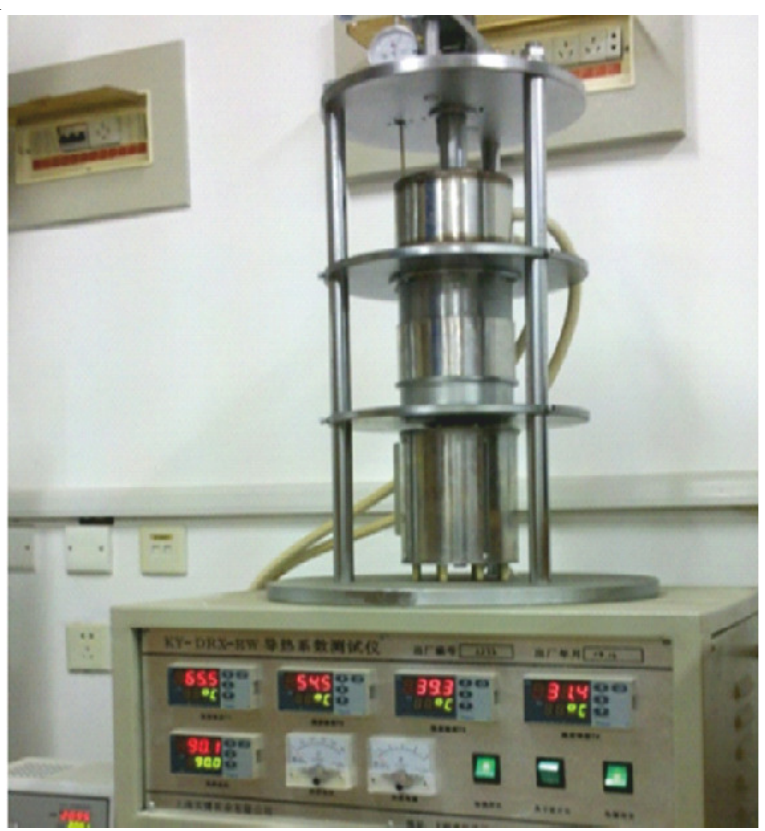

Fig. 4. KY-DRX-RW tester

\section{RESULTS AND DISCUSSION}

Friction coefficient: Friction coefficient curves of the fabric self-lubricating liners filled with different content graphite are shown in Fig. 5. For all types of the liners, the friction coefficient maintained around 0.030-0.043 during the stable friction stage (2500-7200 s). Among these four types of the fabric self-lubricating liners filled with graphite, $10 \mathrm{wt}$ \% graphite filled liner showed a smoother and steadier friction coefficient curve than other kinds of liners. By contrast, friction coefficient curves of liners with 20 and 30 wt. \% graphite were volatile, especially the one filled with $30 \mathrm{wt}$. \% graphite. The fabric liner without filler showed the lowest friction coefficient level. However, at beginning of stable friction stage (2500$5000 \mathrm{~s}$ ), small but frequent fluctuation appeared in the friction coefficient curve of the liner without filler while intensive and sharp fluctuation peaks were the main characteristic after friction time of $5700 \mathrm{~s}$. These phenomenons indicated that the friction state of the liners except for the one with $10 \mathrm{wt}$. \% graphite were unsteady under the working condition this paper mentioned, which was a great disadvantage for the spherical plain bearings in practicing.

Wear loss: Wear losses of the fabric self-lubricating liners filled with different content graphite are shown in Fig. 6. From the figure, the wear losses of the liners without filler and filled with $30 \mathrm{wt}$. \% graphite were more than $0.2 \mathrm{~mm}$ which is near the wear loss limit. On the contrary, the wear loss of the liner filled with $10 \mathrm{wt}$. \% graphite was only $0.1216 \mathrm{~mm}$ and was decreased by $43.4 \%$ compared with the liner without filler. The wear loss situation of the liner filled with $20 \mathrm{wt}$. \% graphite was in between.

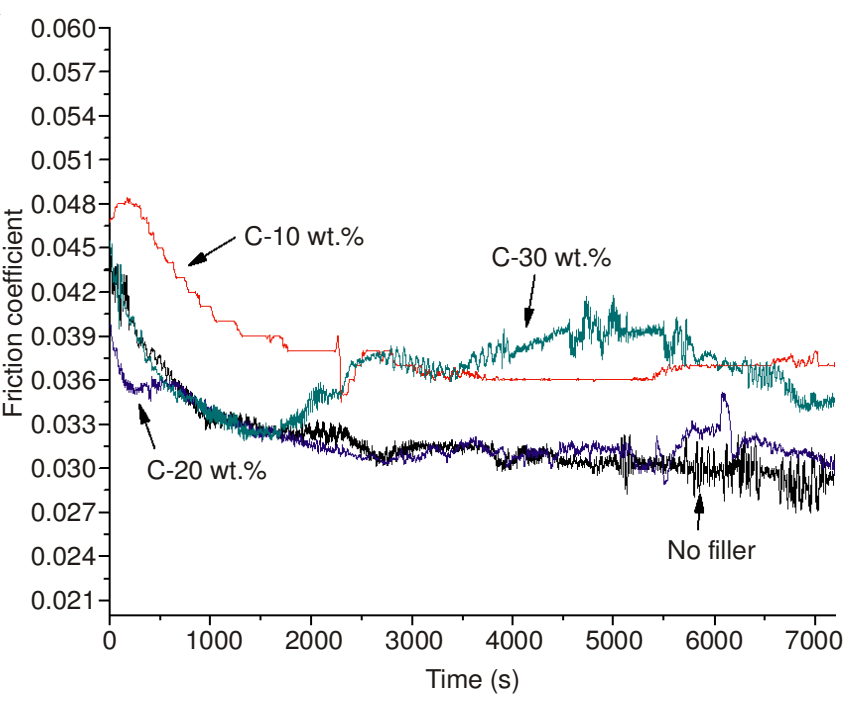

Fig. 5. Friction coefficient curves of the fabric self-lubricating liners

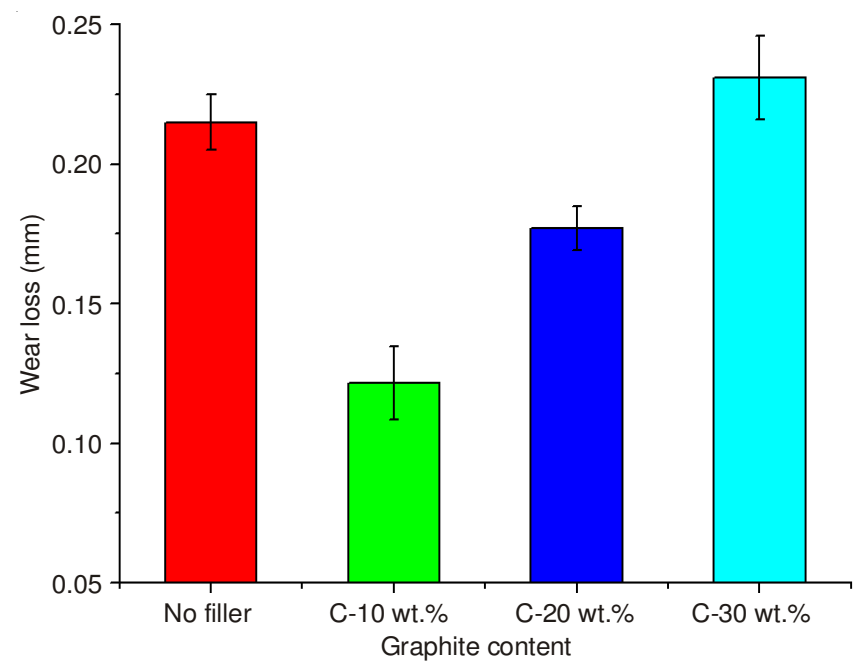

Fig. 6. Wear losses of the fabric self-lubricating liners

Worn morphology: CLSM morphologies of the worn surface of the fabric self-lubricating liners filled with different content graphite are shown in Fig. 7. The surface of the liner without filler was worn severely as shown in Fig. 7a. Tissues of the weave structure were invisible and the tribofilm was disorderly and uneven. In contrast the complete tissues of the weave structure of the worn surface of the fabric liner filled with 10 wt. \% graphite were clearly visible. The tribofilm was uniform and most of the PTFE fiber remained unbroken, as shown in Fig. 7b, which indicated that the antifriction property of the liner was significantly improved. As the graphite content increased to $20 \mathrm{wt}$. $\%$, mild wear was observed and plenty of uniform tribofilm covered on the worn surface of the liner. The weave structure of the liner could be roughly recognized but a certain amount of the PTFE fiber was consumed away, as shown in Fig. 7c. Worn surface of the liner filled with 30 wt. \% graphite shown in Fig. 7d was severely damaged. The weave structure of the fabric matrix was basically destroyed and tribofilm covered on worn surface discontinuously and unevenly.

Thermal conductivity: Fabric self-lubricating liners filled with different content graphite were performed thermal 

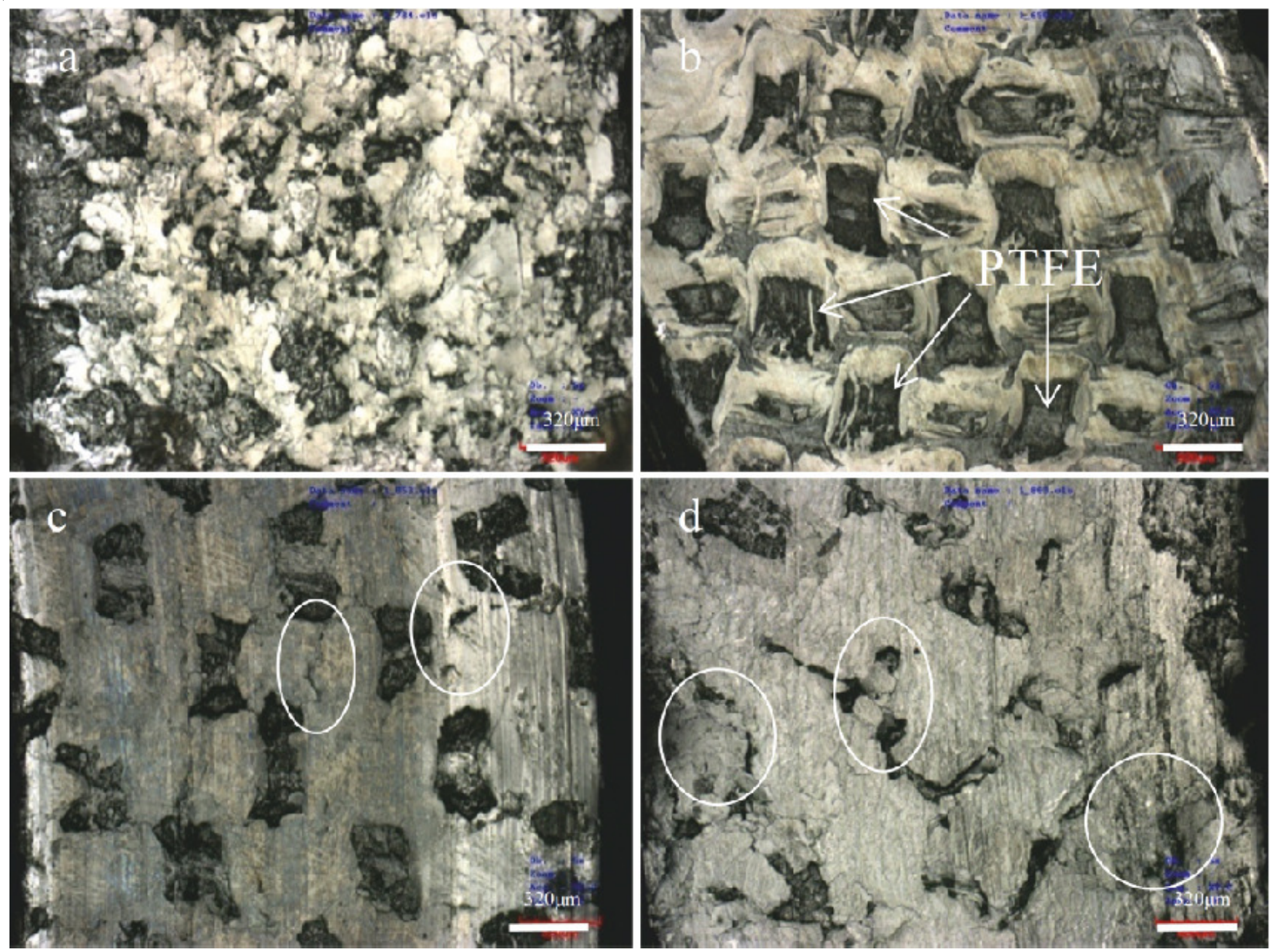

Fig. 7. CLSM morphologies of the worn surface of the fabric self-lubricating liners filled with (a) no filler, (b) 10 wt. \% graphite, (c) 20 wt. $\%$ graphite and (d) $30 \mathrm{wt}$ \% graphite

conductivity testing. To exhibit the result expediently, temperatures of $35,45,75$ and $85^{\circ} \mathrm{C}$ concisely represent ranges of $40-45,50-55,85-95$ and $105-115^{\circ} \mathrm{C}$, respectively. The thermal conductivity results are shown in Fig. 8.

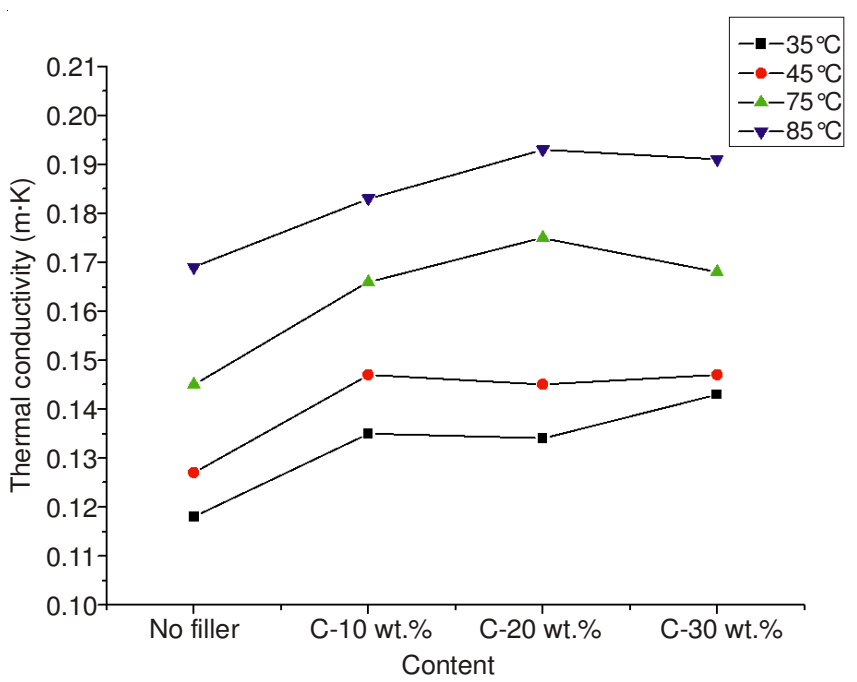

Fig. 8. Thermal conductivities of the liners with different content graphite filler under various temperatures
As shown in the figure, addition of graphite obviously improved the thermal conductivity of the fabric self-lubricating liner. Among the three contents of graphite additive, $10 \mathrm{wt} . \%$ additive showed better efficiency on the thermal conductivity of the fabric liner, which was increased by 14.4, 15.7, 14.5 and $8.3 \%$ under the four typical temperature ranges, respectively than that of the fabric liner without filler. Under normal temperature range (lower than $55^{\circ} \mathrm{C}$ ), the thermal conductivity didn't increase when the graphite additive content increased from 10 to $20 \mathrm{wt}$ \%. But as the graphite additive content increased to $30 \mathrm{wt} . \%$, the thermal conductivity increased. Under high temperature range $\left(85-115^{\circ} \mathrm{C}\right)$, the thermal conductivity slightly increased when the graphite additive content increased from 10 to $20 \mathrm{wt}$. \% but dropped when the graphite additive content increased to $30 \mathrm{wt} \%$.

The export friction temperature curves of the fabric selflubricating liners filled with different content graphite are shown in Fig. 9. Export friction temperature curves of the fabric self-lubricating liners without filler, filled with $10 \mathrm{wt} . \%$ or 20 wt. \% graphite showed a logarithmic up trending at beginning stage (0-3000 s) of the friction. After the friction time of $4000 \mathrm{~s}$, the export friction temperature curves of these liners gradually reached steady state and the temperature maintained around 122.8-133. $8^{\circ} \mathrm{C}$. Besides, export friction temperatures of the 


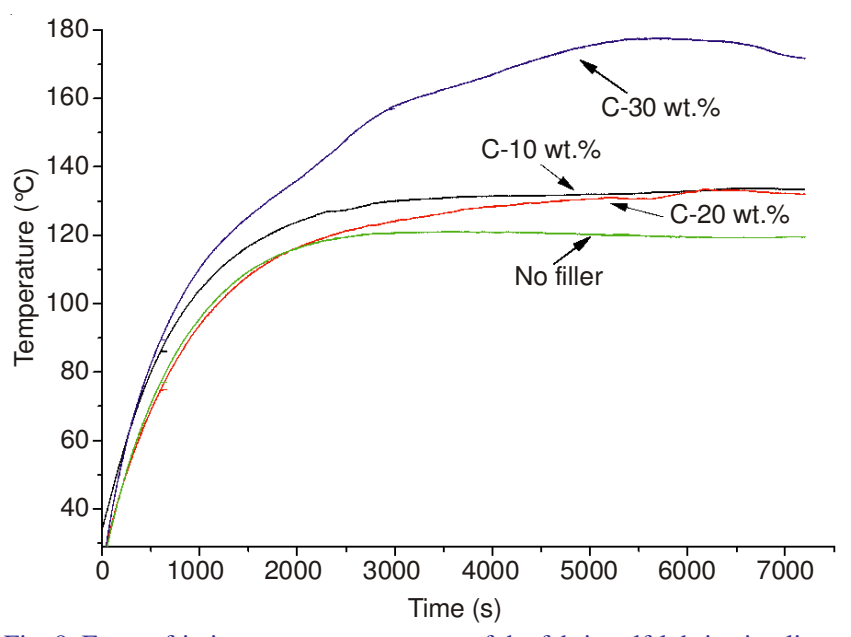

Fig. 9. Export friction temperature curves of the fabric self-lubricating liners

fabric liners filled with 10 and 20 wt. \% graphite were higher than the temperature of the fabric liner without filler, which was consistent with the pattern shown in Fig. 3. On the other hand, export friction temperature of liner filled with $30 \mathrm{wt} . \%$ graphite didn't show a logarithmic trending until about the friction time of $6500 \mathrm{~s}$ and the highest temperature of the fabric liner reached $177.6^{\circ} \mathrm{C}$. It might be caused by the shedding off of the mixture of resin, graphite and polymer that generated in friction due to the high content of graphite filler, which resulted in continuous increasing of the export friction temperature.

According to Suresha et al. ${ }^{10}$, it was the atomic arrangement and the parallel layered structure of graphite which contributed to the enhancement of the tribological performances of the polymer composites. Similarly, the wear resistance of the fabric self-lubricating liner filled with surface modified graphite was improved. Differences of the wear morphologies of different content graphite filled fabric selflubricating liners may be caused by the change of viscosity of the tribofilm. Tribofilm of the fabric self-lubricating liner is mainly comprised of PTFE film and Kevlar fiber/resin debris. Under high friction temperature (higher than $100^{\circ} \mathrm{C}$ ) and pressure, the PTFE film presents a certain viscoelasticity, which maintains the continuity of the tribofilm and provides selflubricating property of the fabric self-lubricating liner. However, after filling graphite powder, which is still structurally integrated under the same friction temperature, viscosity of the tribofilm decreases. The graphite powder breaks the continuity and uniformity of the tribofilm to a certain extent, which explains why the friction coefficients of the fabric self-lubricating liners filled with graphite increases. When the graphite content is relatively low, the influence of the graphite on the tribofilm is weak. Beneficially, it helps to decrease the wear loss and maintain the integrity of the weave structure (Fig. 7b). But when high content graphite powder is added, viscosity of the tribofilm decreases sharply, which causes cracks on the tribofilm and lumpy-looking and intermittent worn surface of the fabric self-lubricating liner (Figs. 7c and 7d). In brief, the wear resistance and thermal conductivity of the fabric selflubricating liner with proper content of surface-modified graphite filler, such as $10 \mathrm{wt}$ \%, were significantly improved while the friction coefficient of the liner slightly increased.

\section{Conclusion}

Thermal conductivity and tribological properties of different content graphite filled fabric self-lubricating liners were investigated. Addition of graphite powder in the fabric selflubricating liner improves its thermal conductivity and the friction heat curves of the graphite filled fabric self-lubricating liners show basically the same pattern with the thermal conductivity curves. Proper content (lower than 20 wt. \%) graphite filler decreases wear loss of the fabric self-lubricating liner but slightly increases the friction coefficient. However, liner filled with $10 \mathrm{wt}$. \% graphite showed higher thermal conductivity which is increased about $15 \%$ when temperature is lower than $100{ }^{\circ} \mathrm{C}$ and lower wear loss which is decreased by $43.4 \%$ compared with the liner without filler. The atomic arrangement and parallel layered structure of graphite help improving the wear resistance of the fabric self-lubricating liner when the additive content is lower than $20 \mathrm{wt}$. \%. But, addition of graphite decreases the viscosity and affects the continuity and uniformity of the tribofilm generated during friction, which results in increase of the friction coefficient and leads to cracks on the tribofilm and lumpy-looking and intermittent worn surface of the fabric self-lubricating liner. Constructively, the wear resistance of the fabric self-lubricating liner decreases with increasing graphite content. In this case, a lower graphite content might be more efficient in improving wear resistance of the liner than that had been attained in this paper.

\section{REFERENCES}

1. L. Cheng and C. Van Der Geld, Heat. Transfer. Eng., 26, 18 (2005).

2. B. Weidenfeller, M. Höfer and R.F. Schilling, Composites Part A, 35, 423 (2004).

3. Z.D. Han and A. Fina, Prog. Polym. Sci., 36, 914 (2011).

4. J. Hong, D.W. Park and, S.E. Shim, Macromol. Res., 20, 465 (2012).

5. M.G. Miller, M.J. Keith, A.J. King, J.B. Edwards, N. Klinkenberg and A.D. Schiraldi, Polym. Compos., 27, 388 (2006).

6. D.C. Moreira, L.A. Sphaier, J.M.L. Reis and L.C.S. Nunes, Exp. Thermal. Fluid. Sci., 35, 1458 (2011).

7. R.J. Kuriber and M.K. Alam, Exp. Heat. Transfer., 15, 19 (2002).

8. D. Kumluta ${ }^{\circ}$, I.H. Tavman and M. Turhan Çoban, Compos. Sci. Technol., 63, 113 (2003).

9. C. T'Joen, Y. Park, Q. Wang, A. Sommers, X. Han and A. Jacobi, Int. J. Refrig., 32, 763 (2009).

10. B. Suresha, G. Chandramohan and N.M. Renukappa, J. Appl. Polym. Sci., 103, 2472 (2007).

11. Z. Zhang, C. Breidt, L. Chang, F. Haupert and K. Friedrich, Compos. Part. A-Appl. S., 35, 1385 (2004).

12. B.S. Tripathy and M.J. Furey, Wear, 162, 385 (1993).

13. F. Li, F. Yan, L. Yu and W. Liu, Wear, 237, 33 (2000).

14. P. Werner, V. Altstädt, R. Jaskulka, O. Jacobs, J.K. Sandler, M.S. Shaffer and A.H. Windle, Wear, 257, 1006 (2004).

15. B. Chen, Q. Bi, J. Yang, Y. Xia and J. Hao, Tribol. Int., 41, 1145 (2008).

16. S. Azeem and M. Zain-ul-Abdein, Int. J. Eng. Sci., 52, 30 (2012).

17. A.Yu, P. Ramesh, M.E. Itkis, E. Bekyarova and R.C. Haddon, J. Phys. Chem. Lett., 111, 7565 (2007).

18. S. Ganguli, A.K. Roy and D.P. Anderson, Carbon, 46, 806 (2008).

19. X. Py, R. Olives and S. Mauran, Int. J. Heat. Mass. Tran., 44, 2727 (2001).

20. H. Fukushima, L.T. Drzal, B.P. Rook and M.J. Rich, J. Therm. Anal. Calorim., 85, 235 (2006). 